\title{
Lung Large Cell Carcinoma by AJCC v7 Stage
}

National Cancer Institute

\section{Source}

National Cancer Institute. Lung Large Cell Carcinoma by A/CC v7 Stage. NCI Thesaurus.

Code $C 136493$.

A term that refers to the staging of large cell lung carcinoma, following the rules of the TNM AJCC v7 classification system. 